\title{
Characterization of Sphaeropsis sapinea Isolates from South Africa, Mexico, and Indonesia
}

Juanita de Wet, Michael J. Wingfield, and Teresa A. Coutinho, Tree Pathology Co-operative Programme (TPCP), Department of Microbiology and Plant Pathology; and Brenda D. Wingfield, Department of Genetics, Forestry and Agricultural Biotechnology Institute (FABI), University of Pretoria, Pretoria, 0002, SOUTH AFRICA

\begin{abstract}
de Wet, J., Wingfield, M. J., Coutinho, T. A., and Wingfield, B. D. 2000. Characterization of Sphaeropsis sapinea isolates from South Africa, Mexico, and Indonesia. Plant Dis. 84:151-156.

Post-hail-associated dieback of Pinus patula and P. radiata trees, induced by Sphaeropsis sapinea (=Diplodia pinea), is a common and important disease in commercial pine plantations. Two morphotypes, A and B, have been described for this fungus based on differences in cultural characteristics, conidial morphology, and virulence among isolates from the north central United States. The existence of the two described morphotypes was later verified through the use of random amplified polymorphic DNA (RAPD) analyses, and the morphotypes were designated as the A and B RAPD marker groups. The objective of this study was to characterize a set of $S$. sapinea isolates from South Africa, Indonesia, and Mexico using RAPD analysis and DNA sequencing of the internal transcribed spacer (ITS) region of the ribosomal DNA operon. Sizes of conidia and culture morphology were, furthermore, used to compare the three groups of $S$. sapinea isolates that emerged from the RAPD analysis. Two of the RAPD groups included isolates from the United States, representing the A and B morphotypes, while the third RAPD group accommodated Indonesian and one Mexican isolate. ITS sequences of all the $S$. sapinea isolates were highly homologous and resolved only the A and B RAPD groups. The ITS sequences of the isolates in the third RAPD group were the same as those of the A RAPD group. Conidia of isolates representing the A and B morphotypes were approximately the same size, but those of the third RAPD group were significantly longer. RAPD analysis enabled us to identify a third group of $S$. sapinea that is different from the well-recognized A and B groups. Isolates in this third RAPD group also have a distinct morphological characteristic and thus represent a third discrete morphological group, which we refer to as the C morphotype of $S$. sapinea.
\end{abstract}

Sphaeropsis sapinea (Fr.:Fr.) Dyko \& Sutton in Sutton (=Diplodia pinea (Desmaz.) J. Kickx fil.) is an opportunistic pathogen of conifers $(1,3,6,7,16)$. It has a worldwide distribution and is well known for the damage it causes to exotic pine plantations $(9,11,20,21,29)$. In South Africa, the fungus is an important pathogen of various Pinus spp. (10,15,33,34). Predisposition of the host plays an essential role in the initiation of $S$. sapinea infections by reducing tree resistance or by providing infection sites $(14,16,35)$. Predisposition factors include extreme environmental conditions or physical wounding through hail and pruning $(2,18,30)$. In South Africa, the common occurrence of hailstorms enhances the susceptibility of Pinus radiata and $P$. patula trees to infection by $S$. sapinea,

E-mail: mike.wingfield@fabi.up.ac.za

Accession numbers: AF027758 (94.07), AF027757 (94.05), AF027756 (93.31).

Accepted for publication 21 October 1999.

Publication no. D-1999-1129-02R

(C) 2000 The American Phytopathological Society
Corresponding author: M. J. Wingfield resulting in substantial timber losses each year $(11,14,39)$.

Infection by $S$. sapinea results in various disease symptoms, of which dieback is the most common (17). Other symptoms frequently associated with $S$. sapinea infec- tion include whorl cankers $(16,38)$, root disease (37), and crown wilt (8). The fungus was also found as a saprophytic inhabitant of sapwood, resulting in blue stain (13). In cone and stem tissue of healthy pine trees, $S$. sapinea was found to exist as an endophyte $(26,29)$. As an endophyte, the fungus is in a latent state and only results in disease symptoms if the host becomes stressed.

Two morphotypes of $S$. sapinea have been described in the United States $(19,34)$. These are characterized based on differences in conidial dimension, cell wall morphology, mycelial appearance, growth rate in culture, virulence, and isozymes $(19,32,34)$. The A morphotype has fluffy white to gray-green mycelium and grows faster than the B morphotype (4). The B morphotype has white to black mycelium appressed to the agar. The A morphotype was also reported to be more virulent than the B morphotype. The categorization of $S$. sapinea isolates from the United States into two groups based on morphology is furthermore supported through random amplified polymorphic DNA (RAPD) analysis (A and B RAPD marker groups) $(5,23,26)$.

While a substantial effort has been made to characterize isolates of $S$. sapinea in the United States by categorizing them into groups based on morphology, virulence,
Table 1. Sphaeropsis sapinea isolates used in this study

\begin{tabular}{|c|c|c|c|c|}
\hline Isolates $^{\mathbf{a}}$ & Morphotype & Host & Origin & Collector \\
\hline CMW 190* & A & Pinus banksiana & United States & M. A. Palmer \\
\hline CMW 4329* & A & $P$. ponderosa & United States & G. A. Stanosz \\
\hline CMW 4332 & A & P. nigra & United States & G. A. Stanosz \\
\hline CMW 189* & B & $P$. resinosa & United States & M. A. Palmer \\
\hline CMW4333* & B & P. resinosa & United States & G. A. Stanosz \\
\hline CMW4334 & B & P. resinosa & United States & G. A. Stanosz \\
\hline CMW4876* & Unknown & P. patula & Indonesia & M. J. Wingfield \\
\hline CMW4877* & Unknown & P. patula & Indonesia & M. J. Wingfield \\
\hline CMW4878* & Unknown & P. patula & Indonesia & M. J. Wingfield \\
\hline CMW4879* & Unknown & P. patula & Indonesia & M. J. Wingfield \\
\hline CMW4880* & Unknown & P. patula & Indonesia & M. J. Wingfield \\
\hline CMW4886 & Unknown & P. patula & Indonesia & M. J. Wingfield \\
\hline CMW4881* & Unknown & P. patula & Indonesia & M. J. Wingfield \\
\hline CMW4883* & Unknown & P. patula & Indonesia & M. J. Wingfield \\
\hline CMW4885 & Unknown & P. patula & Indonesia & M. J. Wingfield \\
\hline CMW1185* & Unknown & P. radiata & South Africa & M. J. Wingfield \\
\hline CMW4896 & Unknown & P. greggii & Mexico & M. J. Wingfield \\
\hline CMW4897 & Unknown & P. greggii & Mexico & M. J. Wingfield \\
\hline CMW4898* & Unknown & P. greggii & Mexico & M. J. Wingfield \\
\hline CMW4899* & Unknown & P. greggii & Mexico & M. J. Wingfield \\
\hline
\end{tabular}

a Isolates CMW4329, CMW4332, CMW4333, and CMW4334 are also known as 94-35, 95-69, 215, and 474 , respectively, in the collection of G. Stanosz. Isolates marked with an asterisk $(*)$ were included in comparisons of cultural and conidial characteristics. 
and RAPDs, very little work has been conducted on differentiation within the species from other parts of the world. In South Africa, some isolates have the same characteristics as A morphotype isolates from the United States based on isozyme profiles, but no South African isolates were found to have characteristics typical of B morphotype isolates (32). The objective of this study was to characterize a set of $S$. sapinea isolates from South Africa, Mexico, and Indonesia based on comparisons with standard isolates from the United States representing the $\mathrm{A}$ and $\mathrm{B}$ RAPD marker groups using RAPD analysis, as previously described (23), internal transcribed spacer (ITS) sequence comparisons, and culture and conidial morphology.
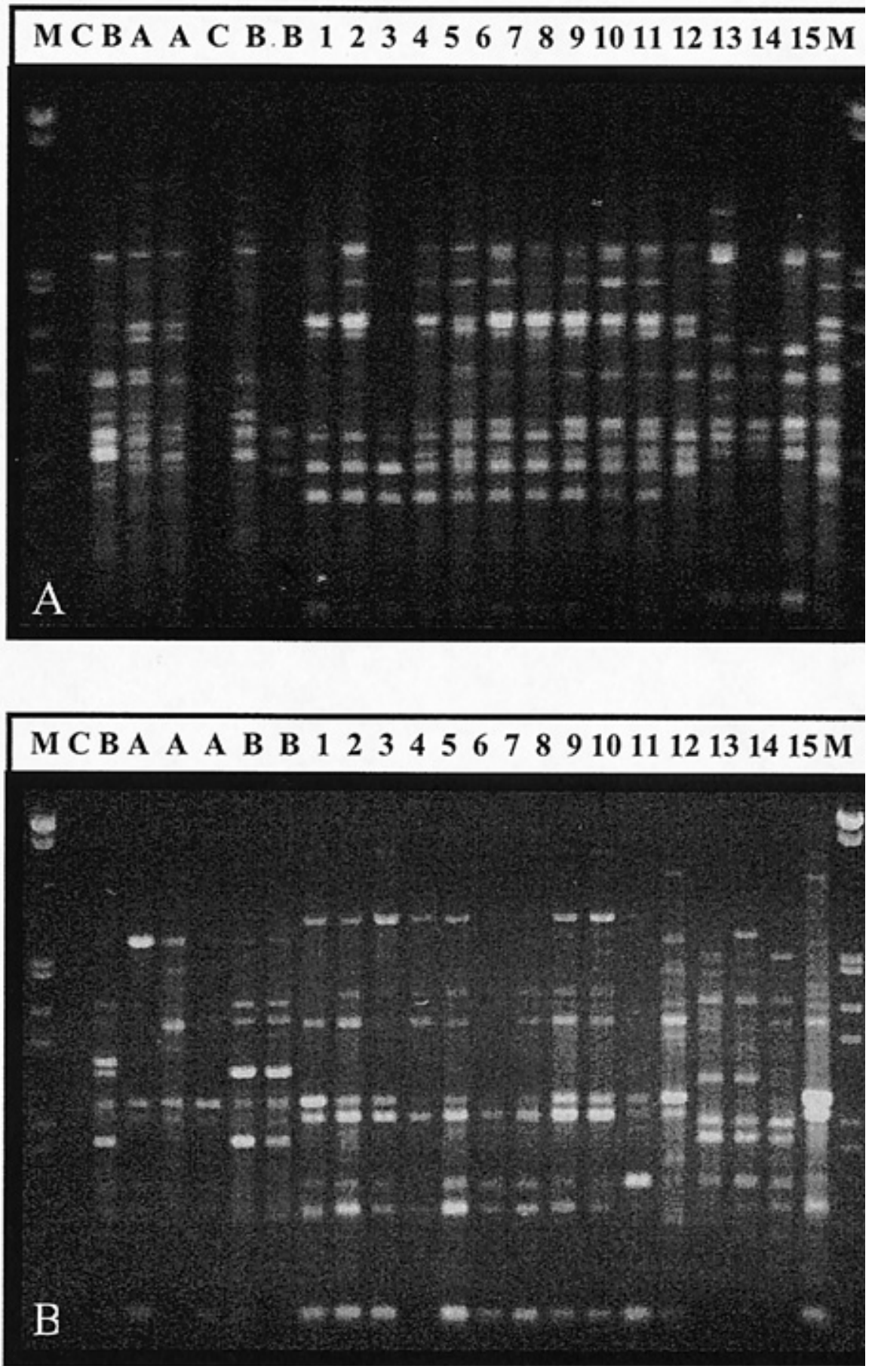

Fig. 1. Random amplified polymorphic DNA (RAPD) gel profiles for various Sphaeropsis sapinea isolates. (A) Primer DS2 (B) Primer DS3. Lane M, molecular weight marker ( $\lambda$ DNA cut with HindIII and EcoRI); lane C, water control; lane A, United States RAPD group A (CMW190, CMW4329, CMW4332); lane B, United States RAPD group B (CMW189, CMW4334, CMW4333); lanes 1 to 10, Indonesia (CMW4876, CMW4877, CMW4878, CMW4879, CMW4880, CMW4886, CMW4887, CMW4881, CMW4883, CMW4885); lane 11, South Africa (CMW1185); lanes 12 to 15, Mexico (CMW4896, CMW4897, CMW4898, CMW4899).

\section{MATERIALS AND METHODS}

Fungal isolates. A set of $20 \mathrm{~S}$. sapinea isolates obtained from various sources was used in this study (Table 1). The South African and Mexican isolates were obtained by direct isolation from the pith tissue of $P$. patula cones, and Indonesian isolates were obtained from pycnidia on $P$. patula shoots with dieback symptoms. $S$. sapinea isolates from the United States representing the A and B RAPD groups were supplied by M. Palmer and G. Stanosz, and were used as comparative standards in all tests (Table 1). All the isolates are maintained in the culture collection of the Tree Pathology Co-operative Programme (TPCP), Forestry and Agricultural Biotechnology Institute (FABI), University of Pretoria, South Africa.

Isolates were transferred to $2 \%$ water agar (WA) (Biolab Diagnostics, Midrand, South Africa), supplemented with sterile pine needles, and incubated at $25^{\circ} \mathrm{C}$ in constant light to induce sporulation. After positive identification based on conidial and pycnidial morphology (28), single conidial isolates were generated, and these were grown on $2 \%$ malt extract agar (MEA) (Biolab) at $25^{\circ} \mathrm{C}$ in the dark. All $S$. sapinea isolates were transferred to $2 \%$ MEA slants and stored at $4^{\circ} \mathrm{C}$.

DNA extractions. DNA was extracted from the freeze-dried mycelium of 24 single conidial isolates of $S$. sapinea from various parts of the world (Table 1) using the technique described by Raeder and Broda (22). The isolates were grown on 2\% MEA petri dishes ( $9 \mathrm{~cm}$ diameter) in the dark at $25^{\circ} \mathrm{C} 1$ week prior to DNA extraction. DNA concentrations of the samples were determined using a spectrofluorometer and diluted to $5 \mathrm{ng} / \mu \mathrm{l}$ for use in RAPD analysis.

RAPD analyses. Primers DS2 (5'CTGCGACTGAATCTTGCAG-3') and DS3 (5'-GCGAAATGTGTCCTTTGATG-3') (25) were used to differentiate between the $\mathrm{A}$ and B morphotypes of $S$. sapinea. The polymerase chain reaction (PCR) conditions and primers used were those described by Smith and Stanosz (23) (first amplification: $3.75 \mathrm{mM} \mathrm{MgCl}_{2}$, second amplification: $1.5 \mathrm{mM} \mathrm{MgCl}$ ). To ensure that the RAPD banding profiles were reproducible, amplification reactions were repeated several times with separately extracted DNA. DNA fragments were separated on an $0.8 \%$ agarose $(\mathrm{wt} / \mathrm{vol})$ gel (Promega, Madison, WI) containing ethidium bromide $(10 \mu \mathrm{g} / \mathrm{ml})$. From each sample, $15 \mu \mathrm{l}$ was electrophoresed in Trisboric acid-EDTA (TBE) ( $\mathrm{pH}$ 8.0) electrophoresis buffer at $100 \mathrm{~V}$ for 2 to $3 \mathrm{~h}$, and the separated fragments were visualized under UV.

The RAPD banding profiles for each primer were scored for the presence or absence of bands. The banding patterns of $S$. sapinea isolates from South Africa, Indonesia, and Mexico were compared 
with those known to be of the A group (CMW190, CMW4329, CMW4332) and the B group (CMW189, CMW4333, CMW4334). The data set was analyzed using the phylogenetic package PHYLIP version 3.5. The distance matrix was calculated through DNADIST using Kimura2 as parameter, and an unrooted tree was generated using the Neighbor-Joining method.

Sequencing. The ITS region of $20 \mathrm{~S}$. sapinea isolates (Table 1) was amplified using primers ITS1 (5'-TCCGTAGGTGAACCTGCGGG-3') and ITS4 (5'GCTGCGTTCTTCATCGATGC-3') (36).
The following temperature profile was used: 3 min initial denaturation at $93^{\circ} \mathrm{C}$ followed by 35 cycles of $45 \mathrm{~s}$ at $58^{\circ} \mathrm{C}, 1.5$ min at $72^{\circ} \mathrm{C}$, and $30 \mathrm{~s}$ at $92^{\circ} \mathrm{C}$. The final cycle consisted of a 15-min primer extension step at $72^{\circ} \mathrm{C}$. A $50-\mu \mathrm{l}$ reaction mixture was used containing 5 units of Taq polymerase, $10 \times$ PCR buffer $(10 \mathrm{mM}$ Tris- $\mathrm{HCl}$, $1.5 \mathrm{mM} \mathrm{MgCl}_{2}, 50 \mathrm{mM} \mathrm{KCl}, \mathrm{pH} \mathrm{8.3),} 25$ $\mathrm{mM} \mathrm{MgCl} 2,2.5 \mathrm{mM}$ each dNTP (all purchased from Boehringer Mannheim Biochemicals, GmbH, Germany), $15 \mathrm{mM}$ each primer (ITS1 and ITS4), $1 \mu \mathrm{l}$ of template DNA (variable concentrations), and sterile water.
Both DNA strands were sequenced using primers ITS1 and ITS4, as well as the internal primers CS2 (5'-CAATGTGCGTTCAAAGATTCG-3') and CS3 (5'-CCAATCTTTGAACGCACATTG-3') (33). Sequencing reactions were carried out using the ABI PRISM Dye Terminator Cycle Sequencing Ready Reaction kit (PE Applied Biosystems, Warrington, Great Britain) and an ABI Prism 377 DNA sequencer (PerkinElmer). All reactions were done using protocols recommended by the manufacturers.

The sequence data for $S$. sapinea isolates, as well as outgroup sequences of Botryosphaeria dothidea and Lasiodiplo-

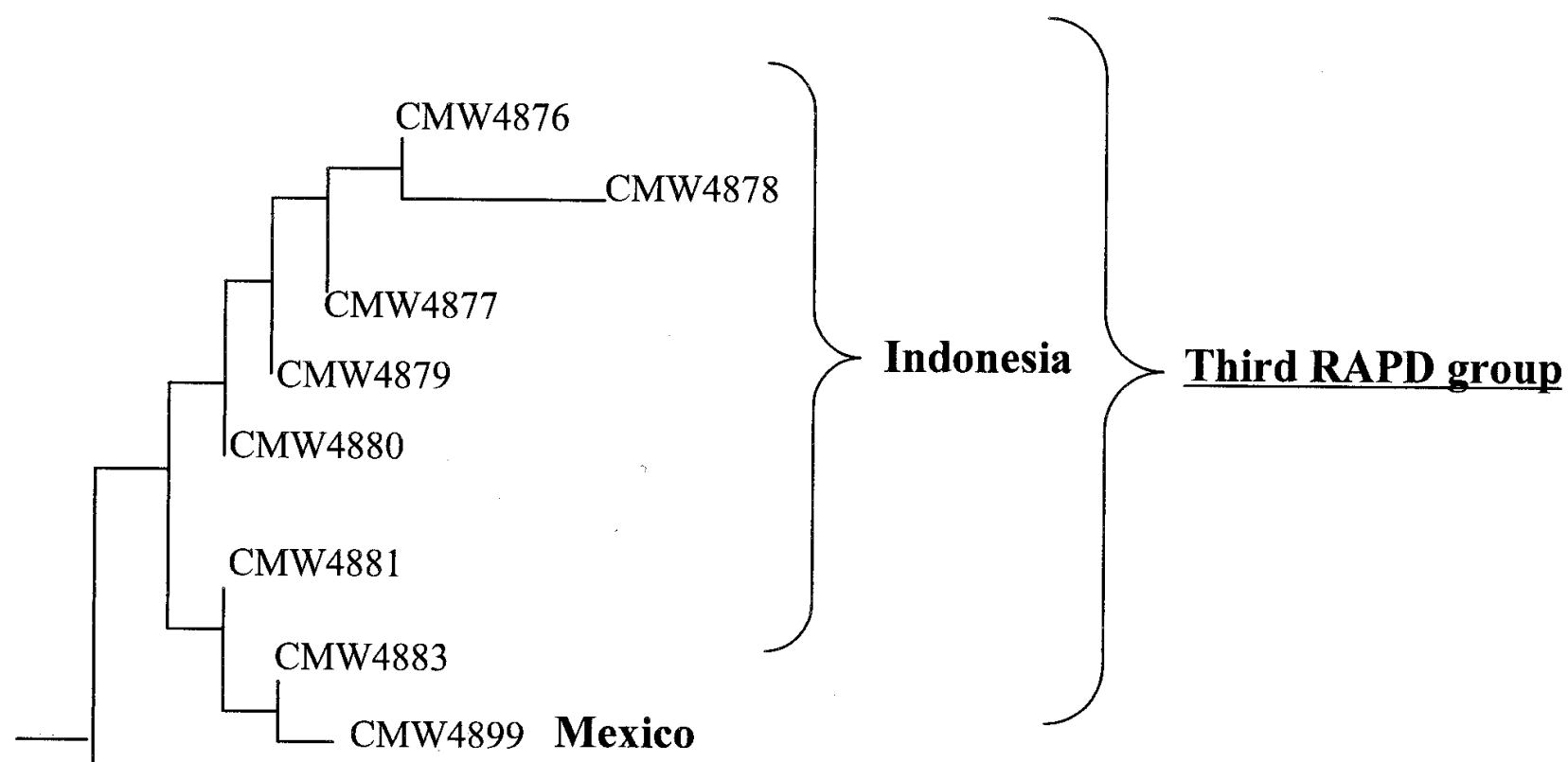

CMW189 B RAPD group

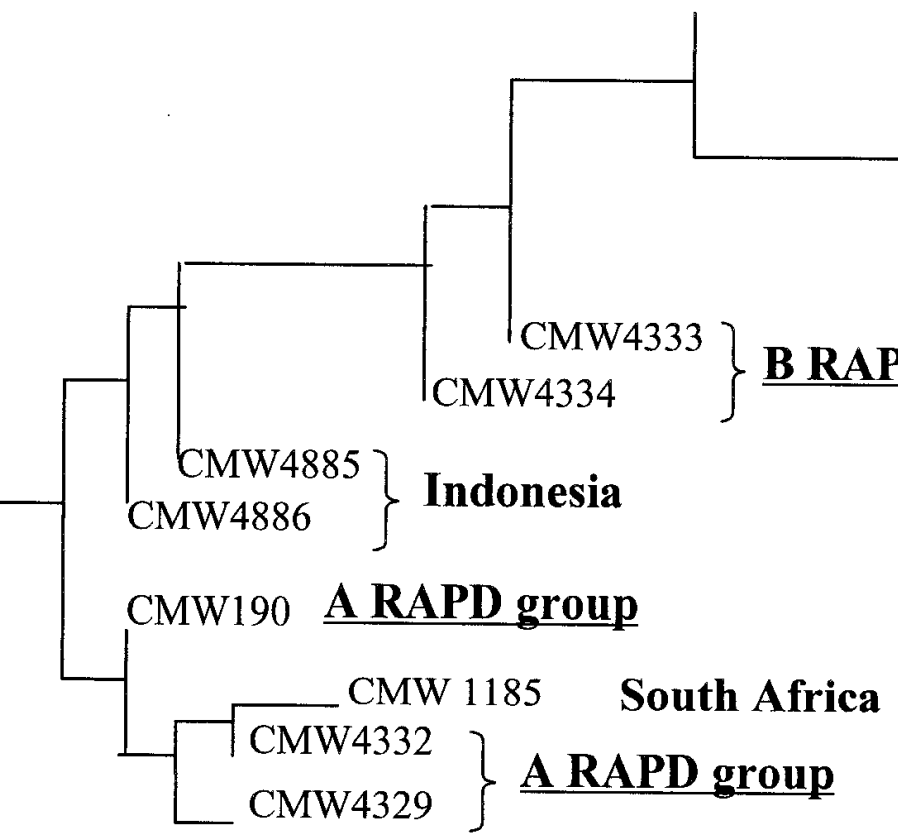

Fig. 2. Dendrogram generated from random amplified polymorphic DNA (RAPD) data for Sphaeropsis sapinea isolates from Indonesia, Mexico, and South Africa, as well as U.S. isolates representing the A and B RAPD marker groups (CMW190, CMW4329, CMW4332, CMW189, CMW4334, CMW4333). The data set was distance analyzed using PHYLIP (version 3.5), with the distance matrix calculated through DNADIST (Kimura-2 parameter), and an unrooted tree was generated using the Neighbor-Joining method. 
dia theobromae, were processed using Sequence Navigator version 1.0.1 (PerkinElmer). These DNA sequences were aligned with each other, as well as with ITS sequences of three $S$. sapinea isolates (94.07-AF027758, 94.05-AF027757, 93.31AF027756) previously sequenced by Jacobs and Rehner (12). Analysis of sequences was achieved using Phylogenetic Analysis Using Parsimony (PAUP) version 3.1.1 (Smithsonian Institution, 1993).
Culture and conidial characteristics. Color and morphology of fungal mycelium on 2\% MEA (Biolab) was noted after 15 days of incubation at $25^{\circ} \mathrm{C}$ in the dark. Conidial morphology and dimensions were also examined after sporulation was successfully induced on 2\% WA (Biolab) supplemented with sterile pine needles and incubation at $25^{\circ} \mathrm{C}$ in constant light. The lengths and widths of 50 conidia per isolate were measured using bright field micros- copy, MicroVideo Capture System, and Auto-Montage (Syncroscopy, Synoptics, LTD, Cambridge, UK). The color of the conidia and the presence of septa were also recorded using bright field microscopy.

\section{RESULTS}

RAPD analyses. RAPD profiles, consisting of 7 to 10 amplified DNA fragments ranging in size from 300 to 1,500 $\mathrm{bp}$, were produced for each of the primers

BSC Botryosphaeria dothide

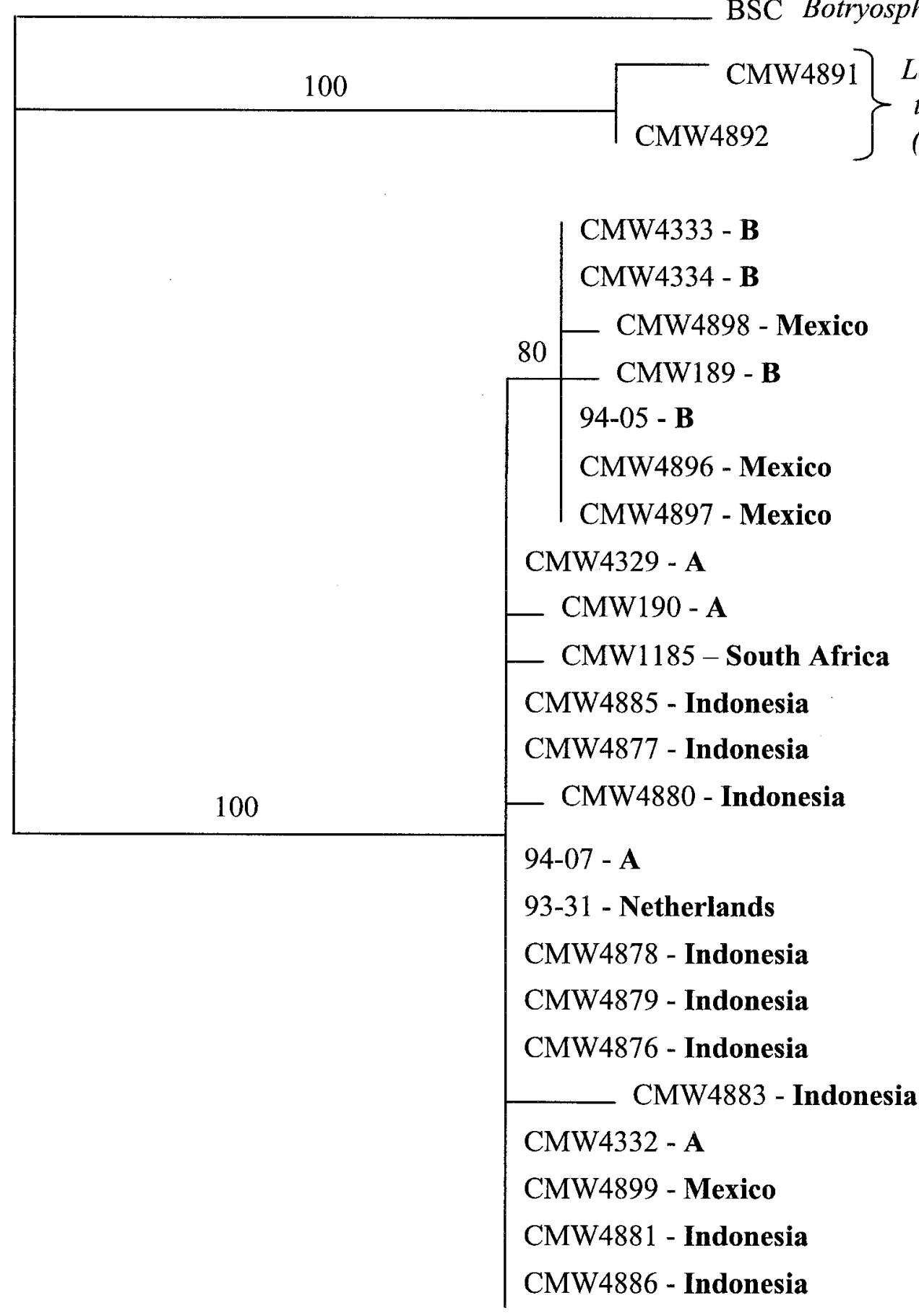

Fig. 3. Dendrogram with bootstrap values (100 replicates) generated from DNA sequence data of the ITS region of the rRNA operon for Sphaeropsis sapinea isolates from Indonesia, Mexico, and South Africa, as well as U.S. isolates representing the A and B RAPD marker groups (CMW190, CMW4329, CMW4332, CMW189, CMW4334, CMW4333) using Phylogenetic Analysis Using Parsimony (PAUP, version 3.1.1). Outgroup sequences of Botryosphaeria dothidea and Lasiodiplodia theobromae, as well as GenBank sequences of three S. sapinea isolates (94.07-AF027758, 94.05-AF027757, 93.31-AF027756), sequenced by Jacobs and Rehner (12), were included. 
DS2 and DS3 (Fig. 1). Using these primers, it was possible to distinguish between the U.S. isolates representing the A and B RAPD groups, which were used as standards. The dendrogram (Fig. 2) generated from the analyses showed that the $S$. sapinea isolate from South Africa (CMW1185) grouped together with standard isolates of the A RAPD group (CMW190, CMW4329, CMW4332). Three of the Mexican isolates (CMW4896, CMW4897, CMW4898) and two of the Indonesian isolates (CMW4885, CMW4886) grouped with standard isolates of the B RAPD group (CMW189, CMW4333, CMW4334). One Mexican isolate (CMW4899) and the remaining seven Indonesian isolates (CMW4876, CMW4877, CMW4878, CMW4879, CMW4880, CMW4881, CMW4883) grouped separately from both the standard A and B RAPD group isolates.

Sequence analyses. Sequences of approximately $540 \mathrm{bp}$ were obtained from the ITS region of the rDNA operon and aligned for $S$. sapinea isolates from Indonesia, Mexico, and South Africa, as well as for standard isolates of the A and B RAPD groups (Fig. 3). The amplified DNA products from one isolate of $B$. dothidea and two isolates of $L$. theobromae, used as outgroups, were similar in size. Sequences of all the $S$. sapinea isolates used in this study had a high degree of similarity. Two single-base-pair differences were observed in the ITS 1 region of the rDNA operon in all the B RAPD group isolates when compared with the A RAPD group isolates. An adenine base was inserted at position 125 and a thymine at position 191 in all the B RAPD group isolates.

The South African S. sapinea isolate (CMW1185) and all the Indonesian isolates had ITS sequences that were very similar to the ITS sequences of the A RAPD group isolates (Fig. 3). One Mexican isolate (CMW4899) had an ITS sequence similar to that of the A RAPD group isolates, and the rest (CMW4896, CMW4897, CMW4898) had a sequence similar to that of the B RAPD group isolates. The isolates of the third RAPD group were indistinguishable from the A RAPD group isolates based on their ITS sequences.

Culture and conidial characteristics. Isolates of the A RAPD group (CMW190 and CMW1885) had fluffy black-white mycelium characteristic of the described A morphotype, and isolates of the B RAPD group (CMW189 and CMW4898) displayed black suppressed mycelium characteristic of the described B morphotype. Isolates of the third RAPD group had either fluffy mycelium or suppressed mycelium and were thus indistinguishable from the A and B morphotypes. The Indonesian isolates in this group (CMW4876, CMW4877, CMW4878, CMW4879, CMW4880, CMW4881, CMW4883) were fluffy, while the Mexican isolate (CMW4899) had my- celium that grew close to the agar surface.

The size of conidia represented the only distinguishable characteristic between the three RAPD groups of $S$. sapinea. The conidia of isolates in the third RAPD group were significantly longer than those of conidia of either the A or B RAPD groups $(\mathrm{df}=2 ; F=15.259 ; P=0.001)$ (Fig. 4). The widths of conidia were not significantly different among the three RAPD groups (df $=2 ; F=0.296 ; P=$ 0.750 ). Length:width ratios were not useful in distinguishing among isolates of the three RAPD groups $(\mathrm{df}=2 ; F=3.570 ; P=$ 0.064).

\section{DISCUSSION}

In this study, we were able to characterize a set of $S$. sapinea isolates from South Africa, Mexico, and Indonesia, and to compare them with the A and B RAPD marker groups using a previously described technique $(23,26)$. Furthermore, we were able to show that a set of isolates from Indonesia and Mexico did not group with standard isolates of the A and B RAPD marker groups. We were also able to correlate molecular differences with differences in morphology for the three RAPD groups. This is the first report of $S$. sapinea isolates grouping outside the two defined RAPD marker groups. Prior to this study, the categorization of $S$. sapinea isolates into A and B RAPD marker groups was done exclusively on isolates collected in the United States. This is the first report where the RAPD technique (23) has been

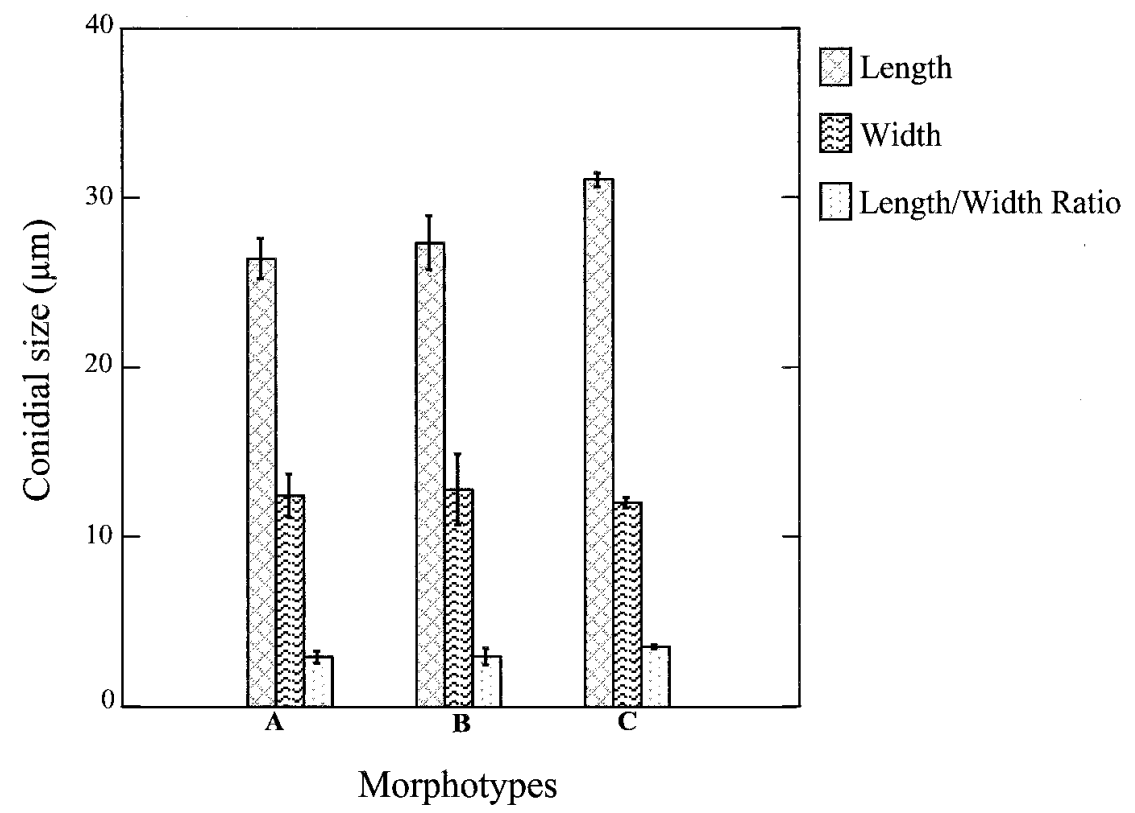

Fig. 4. Mean length, width, and length:width ratios (+/- S.E.M.) of Sphaeropsis sapinea conidia for (A) random amplified polymorphic DNA (RAPD) group isolates (CMW190, CMW4329, CMW1185), (B) RAPD group isolates (CMW189, CMW4333, CMW4898), and eight unique RAPD group isolates (CMW4899, CMW4876, CMW4877, CMW4878, CMW4879, CMW4880, CMW4881, CMW4883). Lengths and widths of 50 conidia per isolate were measured using bright field microscopy, MicroVideo Capture System, and Auto-Montage computer programs. Repeated one-way ANOVAs based on the least squares means were used to analyze data (SYSTAT, version 7.0.1). implemented on S. sapinea isolates from other countries.

Isolates from outside the United States used in this study included those from South Africa, Mexico, and Indonesia. the genus Pinus, and it was perhaps not RAPring to find, together with the B sapinea in this area. This is the first time that the B RAPD group of the fungus has been found outside the United States. Although Indonesia is less richly endowed with Pinus spp., P. merkusii is native in Indonesia, and the third RAPD group of $S$. sapinea was also found in isolates from this area. The fact that the newly defined subgroup of $S$. sapinea occurred in two geographically distant countries (Mexico and Indonesia) suggests that it is probably widespread across the natural range of Pinus. That it has not been found previously is probably linked to the fact that studied in the past.

The origin of S. sapinea in South Africa is not presently known. In the previous study of Swart et al. (32), based on isozyme comparisons, isolates grouped with the A morphotype of the United States. Although based on a very small sample, our study confirmed this result. The apparent occurrence of a single group of $S$. sapinea in South Africa is perhaps unusual given the fact that recent findings indicate that the fungus has probably been repeatedly introduced into the country Mexico represents a center of diversity for 
from a wide range of sources (25).

In this study, ITS sequence data were used in conjunction with the RAPD analysis to compare the $S$. sapinea isolates. Differences in the sequence data were sufficient to separate $S$. sapinea isolates into two groups representing the A and B morphotypes (=A and B RAPD groups). Using these data, it was also possible to distinguish $S$. sapinea from two other well-defined Botryosphaeria spp., B. dothidea and $B$. rhodina (anamorph $=L$. theobromae) . Although only minor differences in ITS sequence occurred between standard isolates of the A and B groups, they were distinguishable from each other based on two single-base-pair differences in the ITS1 region of the rRNA operon. These two differences occurred consistently in all $\mathrm{B}$ group isolates and were never present in isolates of the A group. ITS sequences of the isolates in the third RAPD group were, however, indistinguishable from ITS sequence data from isolates in the A group. The inability to distinguish between the ITS sequences of isolates in the A and third RAPD group indicates that isolates in the $A$ and $B$ groups are well defined, while those in the newly emerging third RAPD group are probably in the process of differentiation from isolates in the A group.

Morphological distinction between $S$. sapinea isolates belonging to the $\mathrm{A}$ and $\mathrm{B}$ morphotypes is based on cultural characteristics and conidial wall texture $(19,34)$. Although these morphological characteristics are variable and not particularly robust (32), isolates belonging to the third RAPD group were clearly distinguishable from the A and B morphotype groups based on conidial size. A study of the morphology of these isolates has thus confirmed the existence of the third RAPD group as a distinct morphological group, which we now refer to as the C morphotype of $S$. sapinea.

\section{ACKNOWLEDGMENTS}

We are grateful to G. Stanosz and M. Palmer for supplying standard S. sapinea isolates representing the A and B RAPD marker groups from the United States. Financial support for this research was provided by the National Research Foundation (NRF) and the members of the Tree Pathology Co-operative Programme (TPCP).

\section{LITERATURE CITED}

1. Barker, J. L. 1979. Geographical variations in spore morphology of Diplodia pinea. For. Comm. Wood Technology Division, New South Wales, Sydney.

2. Bega, R. V., Smith, R. S., Martinez, A. P., and Davis, C. J. 1978. Severe damage to Pinus radiata and $P$. pinaster by Diplodia pinea and Lophodermium spp. on Molokai and Lanai in Hawaii. Plant Dis. Rep. 62:329-331.
3. Birch, T. T. C. 1937. Diplodia pinea in NewZealand. Rev. Appl. Mycol. 16:148.

4. Blodgett, J. T., and Stanosz, G. R. 1997. Sphaeropsis sapinea morphotypes differ in aggressiveness, but both infect nonwounded red or jack pines. Plant Dis. 81:143-147.

5. Blodgett, J. T., and Stanosz, G. R. 1999. Differences in aggressiveness of Sphaeropsis sapinea RAPD marker group isolates on several conifers. Plant Dis. 83:853-856.

6. Brown, B. N., Bevege, D. I., and Stevens, R. E. 1981. Site stress and Diplodia induced dieback and death of hail damaged slash pine. XVII IUFRO Congress, Kyoto, Japan.

7. Buchanan, T. S. 1967. Diplodia twig blight of pine. Pages 189-191 in: Important Forest Insects and Diseases of Mutual Concern to Canada, United States and Mexico. North American Forestry Commission. Canadian Department of Forestry, Ottawa.

8. Chou, C. K. S. 1982. Susceptibility of Pinus radiata seedlings to infection by Diplodia pinea as affected by pre-inoculation conditions. N.Z. J. For. Sci. 12:438-441.

9. Eldridge, K. G. 1961. Significance of Diplodia pinea in plantations. Rev. Appl. Mycol. 41:339.

10. Fisher, J. 1912. Two fungous diseases of coniferous trees. Agric. J. Union S. Afr. 3:389-391.

11. Gibson, I. A. S. 1980. Two pine needle fungi new to Columbia. Trop. Pest Manage. 26:38-40.

12. Jacobs, K. A., and Rehner, S. A. 1998. Comparison of cultural and morphological characters and ITS sequences in anamorphs of Botryosphaeria and related taxa. Mycologia 90:601-610.

13. Laughton, E. M. 1937. The incidence of fungal disease on timber trees in South Africa. S. Afr. J. Sci. 33:377-382.

14. Lückhoff, H. A. 1964. Diseases of exotic plantation trees in the Republic of South Africa. FAO/IUFRO Sympos. Meet. VI.

15. Lundquist, J. E. 1987. A history of five forest diseases in South Africa. S. Afr. For. J. 140:51-59.

16. Marks, G. C., and Minko, G. 1969. The pathogenicity of Diplodia pinea to Pinus radiata D. Don. Aust. J. Bot. 17:1-12.

17. Millikan, C. R., and Anderson, R. D. 1957. Dead top of Pinus spp. in Victorian plantations. Aust. J. For. 21:1-11.

18. Nicholls, T. H., and Ostry, M. E. 1990. Sphaeropsis sapinea cankers on stressed red and jack pines in Minnesota and Wisconsin. Plant Dis. 74:54-56.

19. Palmer, M. A., Stewart, E. L., and Wingfield, M. J. 1987. Variation among isolates of Sphaeropsis sapinea in the North Central United States. Phytopathology 77:944-948.

20. Punithalingam, E., and Waterston, J. M. 1970. Diplodia pinea. CMI Descriptions of Plant Pathogenic Fungi and Bacteria. No. 273. Commonw. Mycol. Inst./Assoc. Appl. Biol., Kew, Surrey, Eng.

21. Purnell, H. M. 1957. Shoot blight of Pinus radiata Don. caused by Diplodia pinea (Desm.) Kickx. Bull. For. Comm., Victoria 5:1-10.

22. Raeder, U., and Broda, P. 1985. Rapid preparation of DNA from filamentous fungi. Lett. Appl. Microbiol. 1:17-20.

23. Smith, D. R., and Stanosz, G. R. 1995. Confirmation of two distinct populations of
Sphaeropsis sapinea in the North Central United States using RAPDs. Phytopathology 85:699-704.

24. Smith, H., Wingfield, M. J., Crous, P. W., and Coutinho, T. A. 1996. Sphaeropsis sapinea and Botryosphaeria dothidea endophytic in Pinus spp. and Eucalyptus spp. in South Africa. S. Afr. J. Bot. 62:86-88.

25. Smith, H., Wingfield, M. J., De Wet, J., and Coutinho, T. A. Genotypic diversity of Sphaeropsis sapinea from South Africa and Northern Sumatra. Plant Dis. In press.

26. Stanosz, G. R., Smith, D. R., and Guthmiller, M. A. 1996. Characterization of Sphaeropsis sapinea from the West Central United States by means of random amplified polymorphic DNA marker analysis. Plant Dis. 80:11751178.

27. Stanosz, G. R., Smith, D. R., Guthmiller, M. R., and Stanosz, J. C. 1997. Persistence of Sphaeropsis sapinea on or in asymptomatic stems of red pine nursery seedlings. Mycologia 89:525-530.

28. Sutton, B. C. 1980. Sphaeropsis sapinea. Pages 120-121 in: Coelomycetes. Commonw. Mycol. Inst./Assoc. Appl. Biol., Kew, Surrey, Eng.

29. Swart, W. J., Knox-Davies, P. S., and Wingfield, M. J. 1985. Sphaeropsis sapinea, with special reference to its occurrence on Pinus spp. in South Africa. S. Afr. For. J. 35:1-8.

30. Swart, W. J., and Wingfield, M. J. 1991. Biology and control of Sphaeropsis sapinea on Pinus species in South Africa. Plant Dis. 75:761-766.

31. Swart, W. J., Wingfield, M. J., and KnoxDavies, P. S. 1987. Factors associated with Sphaeropsis sapinea infection of pine trees in South Africa. Phytophylactica 19:505-510.

32. Swart, W. J., Wingfield, M. J., Palmer, M. A., and Blanchette, R. A. 1991. Variation among South African isolates of Sphaeropsis sapinea. Phytopathology 81:489-493.

33. Visser, C., Wingfield, M. J., Wingfield, B. D., and Yamaoka, Y. 1995. Generic placement of Ophiostoma polonicum amongst the ophiostomatiod fungi. Syst. Appl. Microbiol. 18:403-409.

34. Wang, C.-G., Blanchette, R. A., Jackson, W. A, and Palmer, M. A. 1985. Differences in conidial morphology among isolates of Sphaeropsis sapinea. Plant Dis. 69:838-841.

35. Waterman, A. M. 1943. Diplodia pinea, the cause of a disease of hard pines. Phytopathology 33:1018-1031.

36. White, T. J., Bruns, T., Lee, S., and Taylor, J. 1990. Amplification and direct sequencing of fungal rRNA genes for phylogenetics. Pages 315-322 in: PCR Protocols: A Guide to Methods and Applications. M. A. Innis, D. H. Gelfand, J. J. Sninsky, and T. J. White, eds. Academic Press, San Diego, CA.

37. Wingfield, M. J., and Knox-Davies, P. S. 1980. Association of Diplodia pinea with a root disease of pines in South Africa. Plant Dis. 64:221-223.

38. Wright, J. P., and Marks, G. C. 1970. Loss of merchantable wood in radiata pine associated with infection by Diplodia pinea. Aust. J. For. 34:100-119.

39. Zwolinski, J. B., Swart, W. J., and Wingfield, M. J. 1990. Intensity of dieback induced by Sphaeropsis sapinea in relation to site conditions. Eur. J. For. Pathol. 20:167-174. 